\title{
KAUNO IR MILANO RHO NĖŠČIŲJŲ POŽIŪRIO İ KRYPTINGĄ KŪDIKIO UGDYMĄ PRENATALINIU LAKOTARPIU LYGINAMOJI ANALIZE்
}

\author{
Aušra Lisinskienė, Aida Gaižauskienė \\ Lietuvos kūno kultūros akademija, Kaunas, Lietuva
}

\begin{abstract}
Aušra Lisinskienė. Sporto edukologijos magistrẻ. Lietuvos kūno kultūros akademijos doktorantè. Mokslinių tyrimų kryptis — fizinio aktyvumo poveikis įvairiais žmogaus gyvenimo tarpsniais.
\end{abstract}

\section{SANTRAUKA}

Straipsnyje atskleidžiamas būsimosios mamos emocinis, psichologinis, fizinis santykis su vaiku isčiose. Pasak R. T. Mercer (2001), motinystè, kaip nè vienas kitas socialinis vaidmuo, apima plačiausia socialiniu požiūriu, lūkesčiu ir elgesio modeliu skale, parodo žmogaus raidos stadijas. Šiuo tyrimu siekème išsiaiškinti, ar néščiosioms yra svarbus kryptingas pedagoginis ir fizinis dar negimusio kūdikio ugdymas.

Tyrimo tikslas - išanalizuoti būsimu mamu požiūrị i kūdikio ugdyma prenataliniu laikotarpiu. Iškèlème hipotezę, kad fiziškai ir psichiškai aktyvios néščios moterys palankiau vertina kryptinga kūdikio ugdyma prenataliniu laikotarpiu, ir ju emocinè būsena geresné.

Tiriamosios - sportuojančios ir nesportuojančios Kauno P. Mažylio, Kauno antrosios ligoninès, VŠI „Mama, tėtis ir aš “ bei Milano Rho „Azienda Ospedaliera G. Salvini“ 18 -40 metu néščios moterys.

Šio tyrimo rezultatai buvo palyginti su analogiškai atliktu Italijos mieste Milano Rho (Italijoje). Rezultatu analize parodè, kad: 1) svarbiausiu dalyku, kūdiki ugdant prenataliniu laikotarpiu, tiek lietuvés, tiek italés laiko žalingu ipročiu neturèjima ir gerq nèščiosios emocinę būsenq. Lietuvèms kūdiki ugdyti prenataliniu laikotarpiu dažniausiai trukdo informacijos stoka, o italèms — laiko stoka ( $<<0,05)$; 2) daugiau kaip pusè tirtu lietuviu moteru nurodè, kad néštumo metu jos yra nuolatos fiziškai aktyvios, o italès tik kartais ( $p<0,05)$; tiek lietuvès, tiek italès nurodè, kad mankštintis dažniausiai jas skatina noras pagerinti savo ir mažylio sveikata; italès dažniau nei lietuvès teigè, kad joms fiziškai aktyvioms büti trukdo bloga savijauta nèštumo metu ir laiko stoka $(p<0,05)$; 3) sportuojančios lietuvès dažniau nei italès nurodè, kad néštumo metu labai svarbu neturèti žalingu ipročiu $(p<0,05)$. Nesportuojančios lietuvès dažniau nei italès teigè, kad vaiko ugdymas prenataliniu laikotarpiu priklauso nuo mamos emocinès būsenos $(p<0,05)$. Nesportuojančios italès dažniau nei lietuvès teigè, kad abejoja fizinio aktyvumo nauda tiek besilaukiančiai mamai, tiek mažyliui $(p<0,05)$. Nesportuojančios lietuvès dažniau nei italès nurodè, kad kūdiki ugdyti prenataliniu laikotarpiu joms trukdo informacijos stoka $(p<0,05)$.

Raktažodžiai: néščiosios požiūris, kūdikio ugdymas prenataliniu laikotarpiu, fizinis aktyvumas ir fizinis pasyvumas.

\section{IVADAS}

$\mathrm{G}$ yvename tokiu laikotarpiu, kai viskas labai greitai kinta. Keičiasi požiūris ì gyvybę ir jos prigimtị. Šiuolaikinès visuomenès nebetenkina esami gyvybès apibrèžimai. Čekijoje jau veikia prenatalinio auklejimo organizacijos, šiuo klausimu rašomi moksliniai straipsniai, organizuojamos konferencijos. Atsiranda tokios sąvokos kaip sąmoninga motinystė ir tėvystè, besilaukianti pora, perinatalinè (peri - apie, natalis — gimimas) kultūra. Tai yra nauja žinių sritis, dar tik pradedama atrasti. Prenatalinès ir perinatalinès psichologijos asociacijos prezidento profesoriaus P. Fedor-
Freiberg (2002) teigimu, „nèštumas - tai unikali galimybè išvengti visu psichologinių, emocinių ir fizinių, netgi socialiniu problemų" (cituota iš Markūnienès ir kt., 2003, p. 16).

Motinos ir vaiko ryšys yra vienas pirmujų, užsimezgantis dar vaikui esant isčiose (Lewis, 2005). Šis ryšys yra svarbiausias. Vaikui vystantis jis padeda užmegzti ryšius su kitais jo aplinkos žmonemis (Matthey et al., 2005).

Néštumas yra subtiliausias ir stipriausias moters troškimas, savęs realizavimo raiška, kita vertus, tai kritinis moters gyvenimo laikotarpis. 
Nėščioji susiduria su savo ankstesnio gyvenimo ir dabartinio vaidmens suderinimo problema (Markovienè, Bumblyte, 2004; Obelenienè, Švedas, 2006). Motinystė apibūdinama kaip procesas. Tam, kad jis vyktų harmoningai, reikalingi keli veiksniai: néščios moters emocinis brandumas; pakankama psichinè ir fizinè sveikata; palankios aplinkos sąlygos (ištekèjusios moters statusas, socialinès ir ekonominès aplinkybès) (Mercer, 2001). M. P. Austin ir L. Leader (2000) pažymi, kad motinos nerimas ir patiriami rūpesčiai neigiamai veikia mažylio vystymąsi iki gimimo, ir tai gali sukelti priešlaikini gimdymą bei tiesiogiai statistiškai patikimai koreliuoja su mažu vaiko svoriu. Tai pastebima ir vystantis naujagimiams - néštumo metu patirtas stresas, nerimas gali lemti vaiko elgesio sutrikimus (Huizink et al., 2003; O'Connor et al., 2003; Rodriguez, Bohlin, 2005).

Psichosocialiniai veiksniai nèštumo metu taip pat gali turèti ittakos naujagimių sveikatos būklei. Tyrejjai D. Canivet ir kt. (2005) nurodo, kad tu besilaukiančiu moterų, kurios gyvena ne su būsimu vaiku tèvais, vaikai turi tendenciją susirgti naujagimiu kolika. Jei mama itin jauna, nepalankios ekonominès sąlygos, tai sukelia ittampa, kuri tiesiogiai koreliuoja su blogu vaiko fiziniu vystymusi, nepastoviomis, greitai kintančiomis emocijomis, prastesniu gebejimu mokytis, dirbti (Knackstedt et al., 2005). Kaip jausis něščia moteris, kokia bus jos nuotaika, nuo to priklausys kūdikio visavertis vystymasis.

Yra daug veiklos būdų, padedančių išvengti anksčiau minètu problemų. Viena iš jų - fizinis aktyvumas nėštumo metu, kuris ugdo néščiosios ištvermę, taip svarbią gimdymo metu (Katz, 2002; Tarkan, 2002; Weiss, 2005), ir vaiko fizini vystymąsi įsčiose. Individualūs kineziterapijos specialistų parinkti pratimai koreguoja néščiosios laikyseną, sumažina nugaros skausmus, pagerina savijautą (Čerkauskas ir kt., 2003; Obelienènè, 2006). Reguliariai besimankštinančiujų kūno masė būna mažesnè (Clap, 1995).

Taigi šalies ir užsienio literatūros (tiek mokslinès, tiek metodinès) studijose (Clapp, 1994; Thompson, 1996; Mačiūnienè, 2002; Treuth et al., 2005) pakankamai aprašytas fizinių pratimų fiziologinis poveikis nëščiosios organizmui. Visgi něščios moters požiūris į kryptingą kūdikio ugdymą ir fizinių pratimų poveikį kūdikiui prenataliniu laikotarpiu tèra mažai tyrinètas. Šiuo tyrimu norèjome panagrinèti subjektyvią nèščiujų nuomonę apie lūkesčius, nuostatas, auklëjimo strategiją, dèmesi i kultūrines, socialines ir šeimynines aplinkybes bei fizinę ir psichinę moters sveikatą nèštumo metu. Iškẻlème hipoteze, kad fiziškai ir psichiškai aktyvios néščiosios palankiau vertina kryptingą kūdikio ugdymą prenataliniu laikotarpiu, jų emocinè būsena taip pat geresnè.

Tyrimo tikslas - išanalizuoti Kauno ir Milano Rho nëščiujų požiūrị i kryptingą kūdikio ugdymą prenataliniu laikotarpiu ir jų fizini aktyvumą. Siekiant tikslo buvo užsibrèžti tokie uždaviniai:

1. Atskleisti moterų požiūrị i kūdikio ugdymą prenataliniu laikotarpiu.

2. Išsiaiškinti moterų nuomonę apie fizinio aktyvumo svarbą néštumo metu.

3. Palyginti sportuojančių ir fiziškai neaktyvių néščiujų požiūrị i kūdikio ugdymą prenataliniu laikotarpiu.

\section{TYRIMO METODAI IR ORGANIZAVIMAS}

Tiriant buvo naudotasi anketa, sudaryta remiantis literatūros šaltinių analize, Kauno medicinos universiteto Mokslinio sveikatos centro ir Lietuvos kūno kultūros akademijos socialinių tyrimų grupės anketomis. Laikytasi jų rekomendacijų ir reikalavimų (Kardelis, 2002). Lentelè. Tiriamųjų demografinès
charakteristikos procentinis skirs-
tinys

\begin{tabular}{|c|c|c|c|}
\hline & & Lietuvès & Italès \\
\hline \multirow{4}{*}{ Amžius } & Iki $20 \mathrm{~m}$. & 5,5 & 0 \\
\hline & $21-30 \mathrm{~m}$. & 80 & 29,4 \\
\hline & $31-40 \mathrm{~m}$. & 14,5 & 67,6 \\
\hline & $41 \mathrm{~m}$. ir daugiau & 0 & 3 \\
\hline \multirow{4}{*}{ Išsimokslinimas } & Aukštasis & 58,2 & 32,4 \\
\hline & Koledžas / kolegija & 0 & 50 \\
\hline & Vidurinis & 32,7 & 14,7 \\
\hline & Nebaigtas vidurinis & 9,1 & 2,9 \\
\hline \multirow{4}{*}{ Šeimyninè padètis } & Ištekëjusi & 70,9 & 64,7 \\
\hline & Netekèjusi & 1,8 & 11,8 \\
\hline & Susižadèjusi & 18,2 & 2,9 \\
\hline & Gyvena su draugu & 9,1 & 20,6 \\
\hline
\end{tabular}


Anketą sudarè 21 atviro, uždaro ir filtruojamojo tipo klausimai. Anketoje išskirtos kelios klausimų grupès: pirma - něščiujų emocinè ir fizinè būsena nèštumo metu; antra - požiūris i mažylio ugdymą prenataliniu laikotarpiu; trečia - laisvalaikio leidimo formų vertinimas; ketvirta - požiūris i̇ žalingus ipročius; penkta - néščiuju požiūris ị fizini aktyvumą; šešta - bendrieji klausimai apie socialini statusa. Šiame straipsnyje analizuojami respondenčių atsakymai, susiję su pirma, antra, ketvirta ir penkta anketos klausimu grupe.

Tyrimo duomenys apdoroti SPSS 13 versijos kompiuterine programa. Rezultatai išreikšti procentais. Duomenys statistiškai reikšmingi, jei paklaidos tikimybė $p<0,05$. Statistinis ryšys vertintas taikant chi kvadrato kriteriju $\left(\chi^{2}\right)$.

Tiriamosios - sportuojančios ir nesportuojančios Kauno P. Mažylio, Kauno antrosios ligoninès, VŠI „Mama, tètis ir aš“ bei Milano Rho „Azienda
Ospedaliera G. Salvini“ $18-40$ metų něščios moterys (žr. lent.). Tiriamosisos atrinktos atsitiktiniu būdu: 89 nėščios moterys, iš jų 56 nesportuojančios (33 lietuves ir 23 italès) ir 34 sportuojančios (23 lietuvès ir 11 italiu). Tyrimas atliktas $2006 \mathrm{~m}$. sausio ir vasario mènesiais.

\section{REZULTATAI}

Tyrimo rezultatai parodè ( 1 pav.), kad nesportuojančios italès $(72,7 \%$.) prenataliniu laikotarpiu labiau vertina pedagogines žinias nei lietuvès $\left(45,5 \%\right.$.). Atlikus $\chi^{2}$ kriterijaus skaičiavimus $(\mathrm{df}=3)$, aptiktas reikšmingas skirtumas tarp grupių $\left(\chi^{2}=8,644 ; \mathrm{p}<0,013\right)$.

Sportuojančios lietuvès $(100 \%)$ dažniau nei italès $(83,3 \%)$ teigè, kad prenataliniu laikotarpiu svarbiau netureti žalingų ipročių ( 2 pav. $)-\mathrm{df}=1$, reikšmingas skirtumas tarp grupių ( $\chi^{2}=3,896$; $\mathrm{p}<0,048)$. Lietuvès taip pat dažniau nurodè gy-
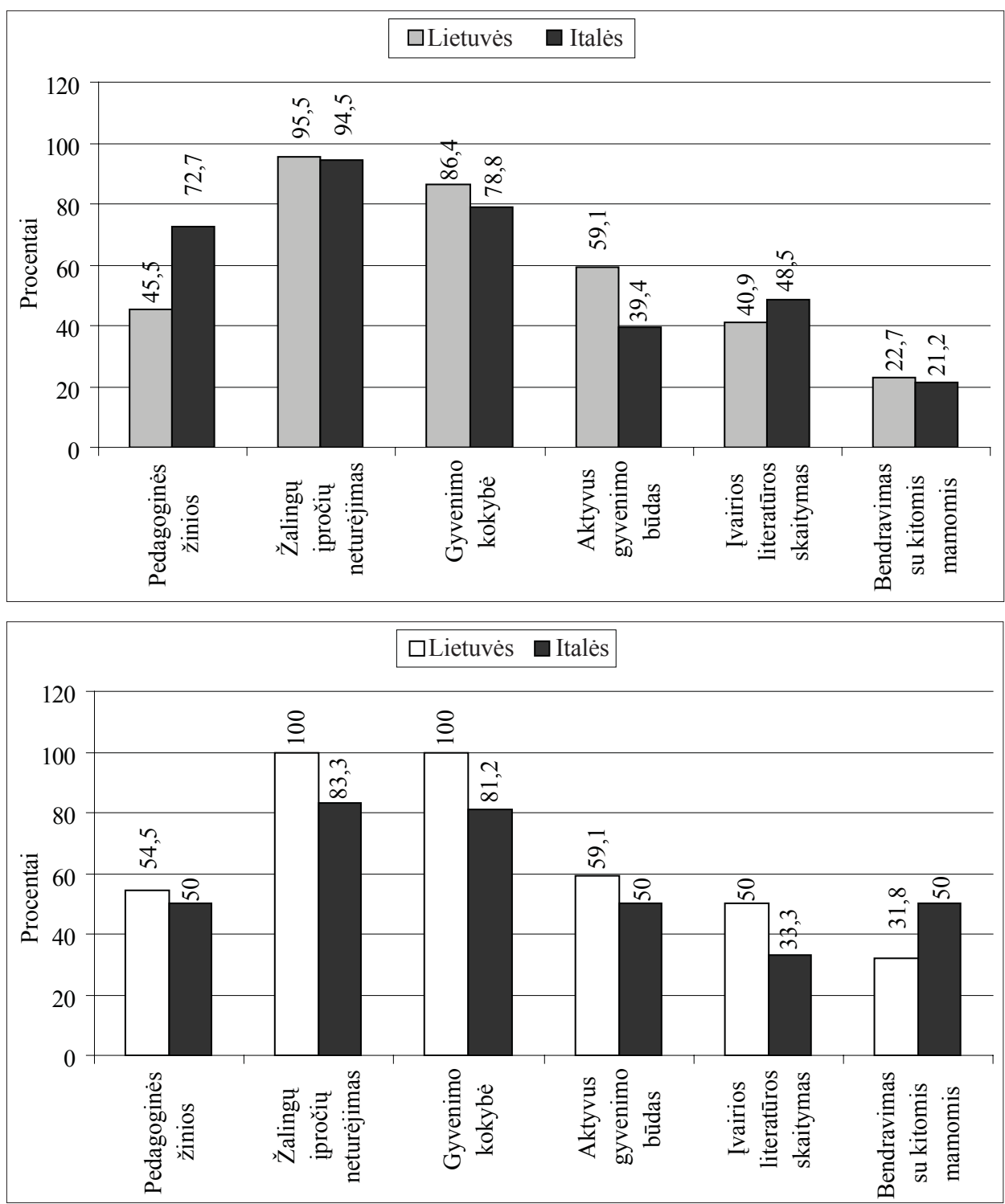

1 pav. Nesportuojančių respondenčių nuomonès apie mažylio ugdymą prenataliniu laikotarpiu procentinis skirstinys

2 pav. Sportuojančių respondenčių nuomonès apie vaiko ugdymą prenataliniu laikotarpiu procentinis skirstinys 
3 pav. Tiriamųjų vertybių svarbos ugdant mažylị prenataliniu laikotarpiu procentinis skirstinys
4 pav. Tiriamųjų nurodomų trukdžių auklèti dar negimusị mažylị procentinis skirstinys
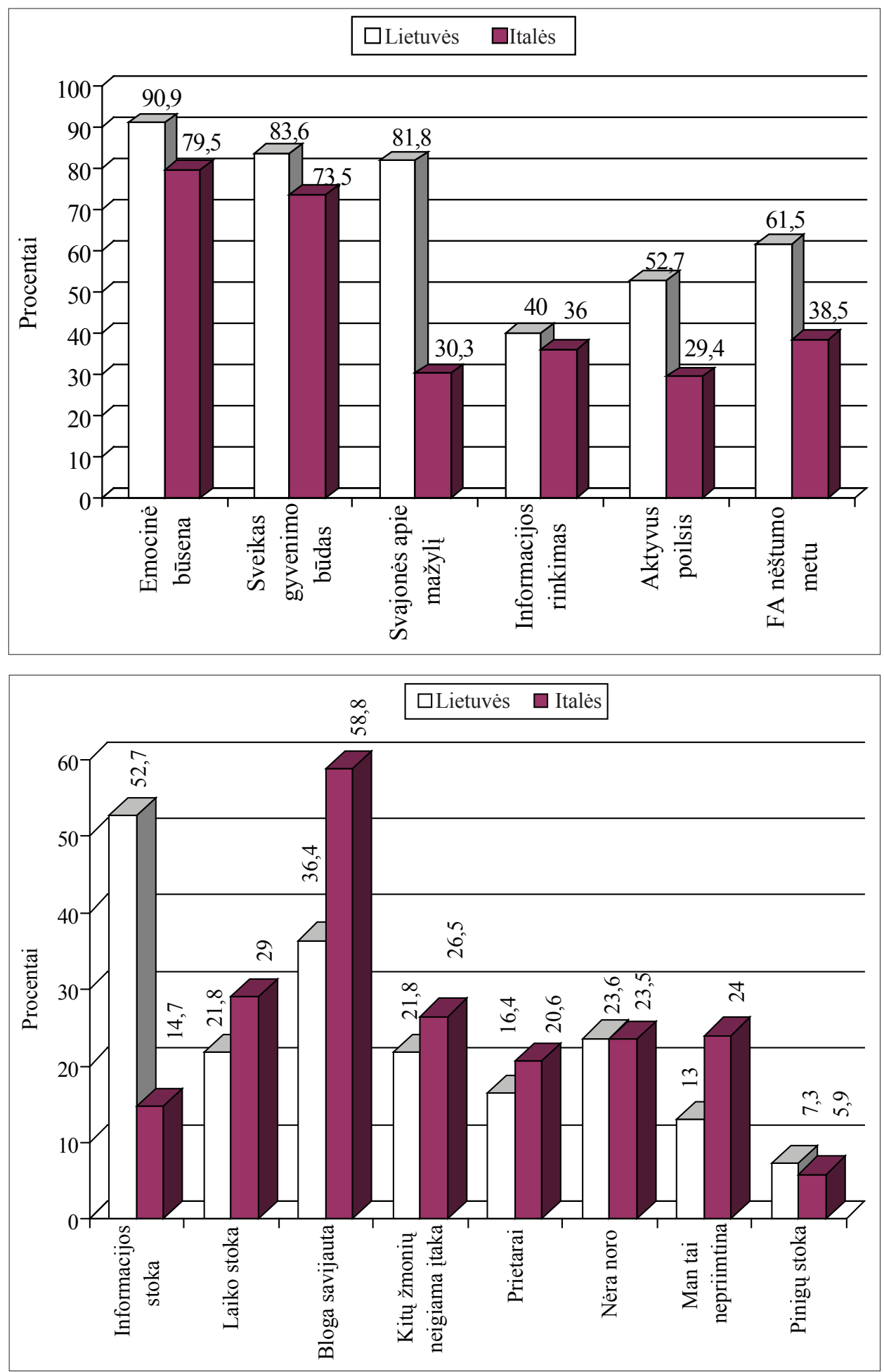

venimo kokybès svarbą - $\mathrm{df}=1$, reikšmingas skirtumas tarp grupiu $\left(\chi^{2}=4,258 ; \mathrm{p}<0,39\right)$.

Domejjomès, kokias vertybes respondentès laiko svarbiausiomis, ugdant mažyli prenataliniu laikotarpiu. Kaip matyti 3 paveiksle, išryškejjo toks skirtumas tarp grupių: lietuvès $(81,8 \%)$ dažniau nei italès $(30,3 \%)$ mano, kad ,labai svarbu svajoti apie mažyli““ $-\mathrm{df}=3$, reikšmingas skirtumas tarp grupiu $\left(\chi^{2}=27,491 ; p<0,000\right)$.
Lietuvès labiau vertina ir ,,aktyvų poilsị nèštumo metu" $\left(\mathrm{df}=2 ; \chi^{2}=10,062 ; \mathrm{p}<0,007\right)$. Šioms respondentems fizinis aktyvumas (FA) taip pat svarbesnis nei italèms $\left(\mathrm{df}=3 ; \chi^{2}=11,533\right.$; $\mathrm{p}<0,009)$.

Tiriant šiu vertybių svarbą tarp nesportuojančių lietuvių ir italių paaiškejjo, kad 93,9\% lietuvių labai svarbi gera emocinè būsena (taip manančių italių buvo $72,7 \%)-\mathrm{df}=1$, reikšmingas 

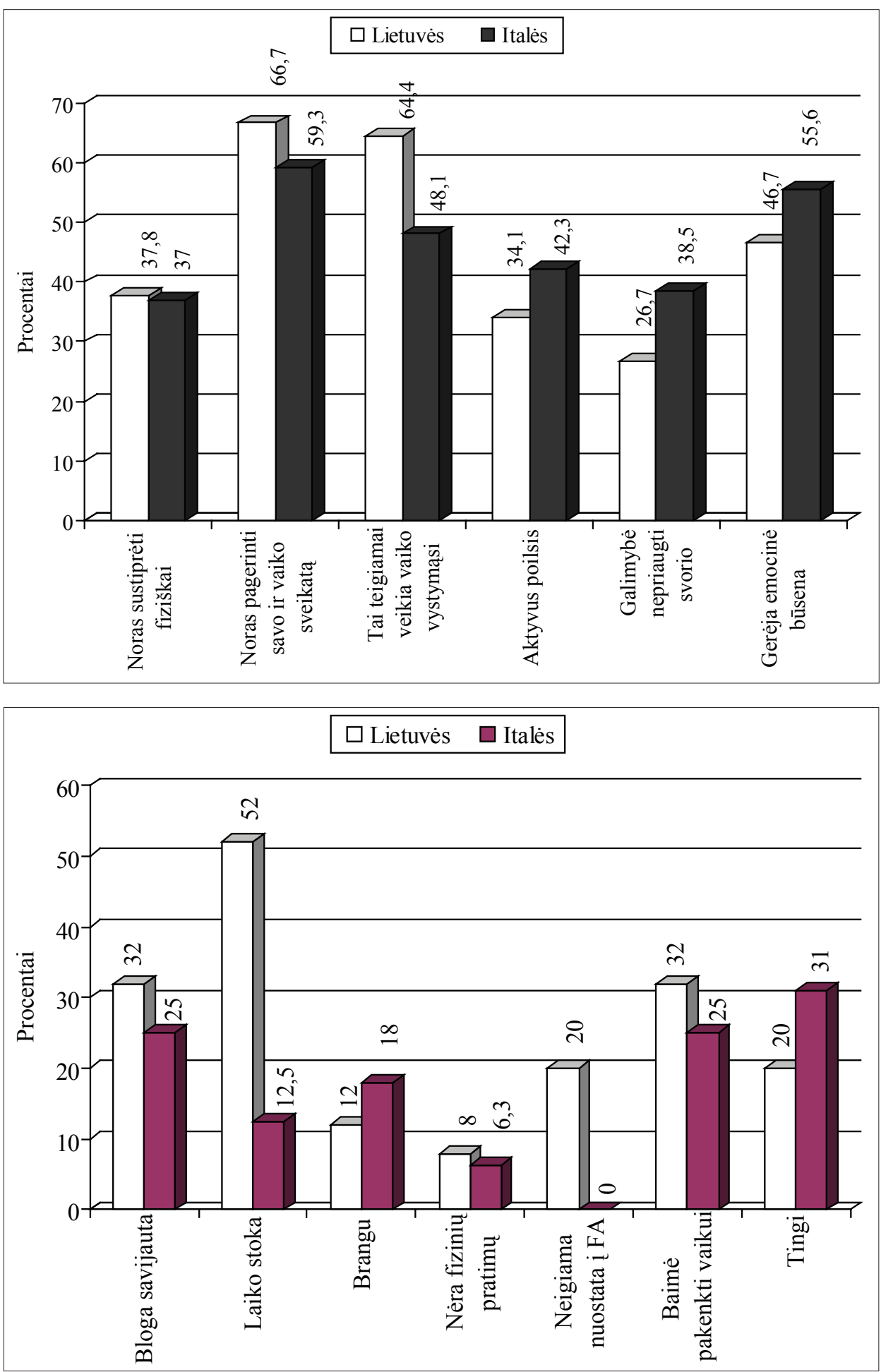

5 pav. Tiriamųjų nurodytų fizinio aktyvumo priežasčių procentinis skirstinys
6 pav. Fiziškai pasyvių tiriamųjų nurodytų nesimankštinimo priežasčių procentinis skirstinys skirtumas tarp grupių $\left(\chi^{2}=4,778 ; p<0,029\right)$. O sportuojančioms lietuvėms (100\%) svarbiau neturèti žalingu ipročių nei italèms $(83,3 \%)-\mathrm{df}=1$, reikšmingas skirtumas tarp grupių $\left(\chi^{2}=3,896\right.$; $\mathrm{p}<0,048)$.

Buvo svarbu išsiaiškinti, kokios priežastys trukdo auklèti dar negimusi kūdiki. Iš tyrimo rezultatų paaiškèjo ( 4 pav.), kad lietuvèms dažniau trukdo informacijos stoka $(52,7 \%)$ nei italèms
$(14,7 \%)-\mathrm{df}=3$, reikšmingas skirtumas tarp grupių $\left(\chi^{2}=12,984 ; \mathrm{p}<0,005\right)$. Italès $(58,8 \%)$ dažniau nurodè blogą savijautą $-\mathrm{df}=3$, reikšmingas skirtumas tarp grupiu $\left(\chi^{2}=9,233 ; \mathrm{p}<0,026\right)$. $24 \%$ tiriamuju teigè, kad „man tai nepriimtina“ $-\mathrm{df}=3$, reikšmingas skirtumas tarp grupiu $\left(\chi^{2}=8,065 ; \mathrm{p}<0,045\right)$.

Taip pat aiškinomès, kas respondentes skatina būti fiziškai aktyvias nèštumo metu (5 pav.). 
Paaiškejjo, kad lietuvès šiek tiek dažniau $(64,4 \%)$ nei italès $(48,1 \%)$ rinkosi atsakymo variantą ,žinau, kad tai teigiamai veikia mažylio vystymąsi“ - $\mathrm{df}=4$, reikšmingas skirtumas tarp grupiu $\left(\chi^{2}=9,847 ; p<0,047\right)$.

Pasidomejome, ar yra didesniu skirtumų tarp fiziškai aktyvių ir pasyvių tiriamujų. Rezultatai parodè, kad sportuojančias lietuves $(81 \%)$ dažniau mankštintis skatina „noras pagerinti vaiko ir savo sveikatą" (taip teigusių italių buvo $33,3 \%)-\mathrm{df}=3$, reikšmingas skirtumas tarp grupiu $\left(\chi^{2}=9,694 ; p<0,021\right)$. Nesportuojančios lietuvès (97\%) dažniau teigè, kad FA ,teigiamai veikia vaiko vystymąsi“ (taip teigusių italių buvo $77,3 \%$ ), tuo tarpu $22,7 \%$ italiu teigé abejojančios tokia nuostata (taip teigusių lietuvių buvo $3 \%)-\mathrm{df}=1$, reikšmingas skirtumas tarp grupiu $\left(\chi^{2}=5,269 ; \mathrm{p}<0,022\right)$.

Analizuojant fizinio aktyvumo svarbą něščiosios organizmui, buvo labai svarbu išsiaiškinti ir nesimankštinimo priežastis. Tyrimo rezultatai (6 pav.) parodè, kad fiziškai pasyvios respondentès dažniausiai nurode šias nesimankštinimo priežastis: lietuvès $(52 \%)$ dažniau nurodè laiko stoką nei italès $(12,5 \%)-\mathrm{df}=4$, reikšmingas skirtumas tarp grupių $\left(\chi^{2}=10,832 ; p<0,029\right)$. Taip pat lietuvès dažniau nurodè ir ,neigiamą nuostatą i fizini aktyvumą nèštumo metu“ - $\mathrm{df}=3$, reikšmingas skirtumas tarp grupiu ( $\left.\chi^{2}=7,988 ; p<0,046\right)$. Trečdalis italių nurodè, kad jos tingi užsiimti fiziškai aktyvia veikla.

\section{REZULTATŲ APTARIMAS}

Hipotezè, kad fiziškai aktyvios nėščiosios palankiau vertina kūdikio ugdymą prenataliniu laikotarpiu ir jų emocinè būklè geresnè - pasitvirtino.

Tyrimo rezultatai parode, kad italès linkusios vèliau planuoti néštumą nei lietuvès. Dauguma tirtų lietuvių (80\%) buvo $21-30$ metų amžiaus, o italiu $(67,6 \%) 31-40 \mathrm{~m}$.

Ugdant kūdikị prenataliniu laikotarpiu, labai svarbus būsimos mamos emocinis nusiteikimas ir noras bendrauti su savo mažyliu. Šiuo tyrimu nustatėme, kad ir lietuvèms $(90,9 \%)$ ir italèms $(79,5 \%)$ labai svarbus emocinis nusiteikimas nèštumo metu. K. Smith (2005) atlikti tyrimai patvirtina šiuos teiginius. Šios autorès teigimu, vaikai, su kuriais motinos kalbasi jiems dar esant įsčiose, galvoja apie juos, skiria jiems daugiau laiko, juos ugdo, kaupia informaciją, kaip visa tai galima kuo efektyviau igyvendinti, jie greičiau susitapatina su savo lytimi. Autorè nurodo, kad vaiko formavimasis prasideda dar jam esant isčiose, kur ir prasideda lyties socializacijos procesas. Tačiau I. Ho ir E. E. Holroyd (2000) Kinijoje atliktas tyrimas parodè, kad didžioji dalis nėščiujų, lankančių pasiruošimo motinystei kursus, patiria netikrumo ir neužtikrintumo savimi jausmą, susijusį su baime tapti motina.

Tyrimai parodè, kad nèščiosios vertina fizini aktyvumą něštumo metu. Joms FA yra svarbus dèl keleto priežasčių: svorio kontrolès, savo ir vaiko sveikatos būklès gerinimo, emocinès būsenos gerinimo. Ž. Mačiūnienès (2002) atliktas tyrimas įrodè, kad per pratybas besimankštinusių něščiujų kūno masè nėštumo pabaigoje buvo $5 \%$, o naujagimio - $10 \%$ mažesnè nei nesimankštinusiujų, taip pat besimankštinusiųju gimdymo trukmè buvo trumpesnè nei nesimankštinusiųų. Nėščiujuc, lankiusių aerobikos pratybas, kūno masès indeksas nèštumo pabaigoje buvo mažesnis už nesimankštinusiujų. Taigi galima teigti, kad fiziniai pratimai teigiamai veikia néščią moterị ir kūdikî. A. Vogel (2006) atliktas tyrimas parode, kad fizini aktyvumą nèštumo metu respondentès vertina kaip sveikatos stiprinimą, aktyvų poilsị, gerą emocinę būseną, sveiką gyvenimo būdą, nuotaiką, visapusišką žmogaus tobulejjimą.

\section{IŠVADOS}

1. Tiek lietuvių, tiek italių požiūris ị kūdikio ugdymą prenataliniu laikotarpiu yra teigiamas. Svarbiausiu teiginiu tiriamosios rinkosi žalingu ipročių neturejjimą ir gerą néščiosios emocinę būseną nèštumo metu. Lietuvèms kūdikį ugdyti prenataliniu laikotarpiu dažniausiai trukdo informacijos stoka, o italèms - laiko stoka $(\mathrm{p}<0,05)$.

2. Paaiškejjo tokia moterų nuomonè apie fizinio aktyvumo svarbą néštumo metu: daugiau kaip pusè tirtų lietuvių moterų nurodè, kad nëštumo metu jos nuolatos yra fiziškai aktyvios, o italès tik kartais $(\mathrm{p}<0,05)$; tiek lietuvès, tiek italès nurodè, kad dažniausiai jas mankštintis skatina noras pagerinti savo ir mažylio sveikatą italès dažniau nei lietuvès teigè, kad joms fiziškai aktyvioms būti trukdo bloga savijauta nëštumo metu ir laiko stoka $(\mathrm{p}<0,05)$.

3. Palyginus fiziškai aktyvių ir nesportuojančių moterų požiūrị i kūdikio ugdymą prenataliniu 
laikotarpiu paaiškejjo, kad: sportuojančioms lietuvèms dažniau nei italèms labai svarbu neturèti žalingų ipročių $(\mathrm{p}<0,05)$. Nesportuojančios lietuvès dažniau nei italès teigé, kad vaiko ugdymas prenataliniu laikotarpiu priklauso nuo mamos emocinès būsenos $(\mathrm{p}<0,05)$. Nesportuojančios italès dažniau nei lietuvès teigè, kad abejoja fizinio aktyvumo nauda tiek besilaukiančiai mamai, tiek ir mažyliui $(\mathrm{p}<0,05)$. Nesportuojančios lietuvès dažniau nei italès nurodè, kad kūdikị ugdyti prenataliniu laikotarpiu joms trukdo informacijos stoka $(\mathrm{p}<0,05)$

Padėka. Kauno P. Mažylio, Kauno antrosios ligoninès, VŠI „Mama, tètis ir aš“ vadovams ir administracijai bei Milano Rho „Azienda Ospedaliera G. Salvini“"vadovui ir administracijai už suteiktą galimybę atlikti mokslinius tyrimus.

\section{LITERATŪRA}

Austin, M. P, Leader L. (2000). Maternal stress and obstetric and infant outcomes: Epidemiological findings and neuroendocrine mechanisms. Aust NZJ Obstet Gynaecol, 40 (3), 331-337.

Clapp, R., Rockey, M., Carpenter, R., Artal, O. (1992). Medicine and Science in Sports and Exercise. USA.

Ho, I. \& Holroyd, E. E. (2002). Chinese women's perceptions of the effectiveness of antenatal education in the preparation for motherhood. Journal of Advanced Nursing, 38 (1), 74-85.

Huizink, A. C, Robles de Medina, P. G., Mulder, E. J., Visser, G. H., Buitelaar, J. K. (2003). Stress during pregnancy is associated with developmental outcome in infancy. Journal of Child Psychology and Psychiatry, 44 (6), $810-818$.

Kardelis, K. (2002). Moksliniu tyrimu metodologija ir metodai. Kaunas: Judex.

Katz, J. (2002). Water Fitness during Your Pregnancy. USA

Knackstedt, M. K., Hamelmann, E., Arck, P. C. (2005). Mothers in stress: Consequences for the offspring. American Journal of Reproductive Immunology, 54, 63-69.

Lewis, M. (2005). The child and its family: The social network model. Human Developmen, 48, 8-27.

Mačiūnienè, Ž. (2002). Adaptuotu aerobikos pratybu poveikis néščiosios ir vaisiaus širdies susitraukimų dažniui standartinio fizinio krūvio metu. Sporto mokslas, 3 (29), $73-77$.

Markovienė, M., Bumblytè, D. (2004). Motinystès psichologija. Vilnius: Presvika.

Markūnienė, E., Obelenienė B., Kulikauskaitė B. ir kt. (2003). Geriausia pradžia: ekologiškos motinystès vadovas ir mamoms, ir téčiams. Kaunas: Už gyvybę.

Matthey, S., Guedeney, A., Starakis, N., Barnett, B. (2005). Assessing the social behavior of infants: Use of the Adbb scale and relationship to mothers's mood. Infant Mental Health Journal, 26 (5), 442-458.

Mercer, R. T. (2001). The process of maternal role attainment over the first year. Nursing Research, 34, $198-204$.
Obelenienè, B., Švedas, E. (2006). Laisvo apsisprendimo nutraukti nẻštumą ir moters teisès i informaciją realizavimo galimybės. Sveikatos mokslai, 1-2, 128-132.

O’Connor, T. G., Heron, J., Golding, J., Glover, V. (2003). Maternal antenatal anxiety and behavioural / emotional problems in children: A test of a programming hypothesis. Journal of Child Psychology and Psychiatry, 44 (7), 1025-1036.

Rodriguez, A., Bohlin, G. (2005). Are maternal smoking and stress during pregnancy related to ADHD symptoms in children? Journal of Child Psychology and Psychiatry, 46 (3), 246-253.

Smith, K. (2005). Prebirth gender talk: A case study in prenatal socialization. Women \& Language, 28 (1), $49-53$.

Tarkan, L. (2002). Fit for pregnancy? From Fit Pregnancy [online]. August/September [cited 2006-02-10]. Avalaible from EBSCO

Treuth, M., Butte, N., Puyau, M. (2005). Pregnancy-related chances in physical activity, fitness, and strength. Fitness and strength in pregnant women. Medicine \& Science in Sports \& Exercise, 832-837.

Vogel, A. (2006). Exercise reduces prenatal risks. From Fit Pregnancy [online]. February/March [cited 2006-0210]. Avalaible from EBSCO.

Weiss, A. K. (2005). Practical exercise advice during pregnancy. From Physician \& Sportsmedicine [online].2005 June [cited 2006-02-10]. Avalaible from EBSCO. 


\title{
COMPARATIVE ANALYSES OF ATTITUDES TOWARDS PURPOSEFUL PRENATAL BABY EDUCATION OF PREGNANT WOMEN FROM KAUNAS AND MILAN RHO
}

\author{
Aušra Lisinskienè, Aida Gaižauskienė \\ Lithuanian Academy of Physical Education, Kaunas, Lithuania
}

\begin{abstract}
According to R. T. Mercer (2001), motherhood of all social roles covers the widest scale of social attitudes, expectations and behavior models and reflects stages of human development.

Pregnant woman has a power of managing the organized matter - inside she forms physical body for incoming soul and imparts her inside traits. Definitely, it is the most important process of the creation in the world. The creator is created - a human being, who will determine our and the world's fate. Our topical question is whether psychological-pedagogic and physical nurture of an unborn child is important for women of today's society. As different scientists hold Fanti, Marcone (1993), future relationship with a child starts forming while in womb, therefore this relationship is grounded in pregnancy. The hypothesis of the survey is: physically active women possess more positive attitudes towards purposeful education of a baby during prenatal period, and their emotional condition is better.

The aim of the survey is: to analyze the attitude of pregnant women to purposeful prenatal baby education and their physical activity. The subjects were pregnant women from Kaunas City P. Mažylis Hospital, the Second hospital, Public Institution "Mother, Father and Me" and Italian "Azienda Ospedaliera G. Salvini”. Their age was 18 - 40 years.

The results of this research were compared with the same research carried out in Milan Rho, Italy.

Research analysis indicated that: 1) both Lithuanian and Italian women considered the absence of harmful habits and the good condition of the pregnant women to be the main factors in the prenatal education of children. Lithuanian women noted that the main hindrance educating the baby in the prenatal age was the lack of information, while the Italian women thought that that was the lack of time $(\mathrm{p}<0.05) ; 2)$ more that half of the Lithuanian women who participated in the research indicated that in their pregnancy they were constantly active, while the Italian women were only sometimes active $(p<0.05)$. Both the Lithuanian women and the Italian women noted that they were encouraged to exercise by the wish to improve their own and their babies' health. The Italian women more often than the Lithuanian women told they could not exercise because they felt bad and did not have enough time while they were pregnant $(p<0.05) ; 3)$ the Lithuanian women going in for sports more often than the Italian women indicated that the absence of harmful habits in the prenatal period was of primary importance. The Lithuanian women who did not go in for sports more often than the Italian women claimed that child education in the prenatal age depended on the emotional condition of the mother $(\mathrm{p}<0.05)$. The Italian women who did not go in for sports compared to the Lithuanian women more often questioned the benefit of physical activity both for the future mother and the baby $(\mathrm{p}<0.05)$. The Lithuanian women who did not go in for sports compared to the Italian women claimed that they could not educate their babies in the prenatal period because of the lack of information $(\mathrm{p}<0.05)$.
\end{abstract}

Keywords: attitude of pregnant women, baby education in the prenatal period, physical activity, physical passiveness.

Gauta 2006 m. rugsejjo 12 d.

Received on September 12, 2006

Priimta 2006 m. gruodžio 6 d.

Accepted on December 6, 2006
Aida Gaižauskienė

Lietuvos kūno kultūros akademija

(Lithuanian Academy of Physical Education)

Sporto g. 6, LT-44221 Kaunas

Lietuva (Lithuania)

Tel +37037302669

E-mail a.gaizauskiene@lkka.lt 